ROCZNIKI PEDAGOGICZNE

Tom 11(47), numer 1 - 2019

DOI: http://dx.doi.org/10.18290/rped.2019.11.1-9

ANNA SZUDRA-BARSZCZ

\title{
O NIEKTÓRYCH BŁĘDACH SUMIENIA I TRUDNOŚCIACH W ICH PRZEKRACZANIU
}

Błędy sumienia są jednym z kluczowych zagadnień etyki pedagogicznej. Zwykle definiuje się je jako działania wbrew normom moralnym i charakteryzuje przez pryzmat świadomości czynu. Tak zatem błędy zawinione to te, których autor dokonał świadomie i dobrowolnie, niejako z premedytacją. Niezawinione to te, które wynikają z błędnego rozpoznania normy. W poniższym opracowaniu zaproponuję nieco inne podejście. Postaram się wykazać, że istnieją błędy sumienia wynikające $\mathrm{z}$ wadliwego rozumienia tej władzy poznawczej. Nie będzie tu jednak chodzić o identyfikację jakiejś szczególnej kategorii błędów, co raczej o pokazanie źródeł wadliwości sumienia tkwiących w zgodzie na określone jego ujęcie. Długotrwałe podejmowanie działań w oparciu o błąd w tej dziedzinie może prowadzić do zakłamania, które - co postaram się pokazać w ostatniej części artykułu - jest błędem najbardziej opornym na zmiany zarówno na polu wychowania, jak i samowychowania.

\section{KONCEPCJA SUMIENIA A JEGO WADLIWOŚĆ}

Bez względu na to czy w naszym najgłębszym przekonaniu uznajemy sumienie za głos Boga, głos rozumu, uczucie, instynkt, czy efekt twórczego działania naszej wolnej woli, raczej wszyscy zgadzamy się co do tego, że jest ono sądem praktycznym determinującym nasze działanie. Sąd ten informuje nas lub wręcz nakazuje, co mamy robić, a czego się wystrzegać lub określa wartość moralną tego, co już dokonane. Pomimo powszechnej zgody na taką definicję, brak

Dr Anna SzUdRA-BARSzCZ - Katedra Pedagogiki Porównawczej i Filozofii Wychowania, Instytut Pedagogiki, Wydział Nauk Społecznych, Katolicki Uniwersytet Lubelski Jana Pawła II; adres do korespondencji: ul. Droga Męczenników Majdanka 70, 20-325 Lublin; e-mail: szudra@kul.pl 
jednomyślności w określaniu zasady sądu sumienia. Dyskusje na tym polu zasadniczo dotyczą zdefiniowania tego, co ostatecznie determinuje kształt normy wydawanej przez sumienie, innymi słowy zmierzają ku związaniu jej z określonym przedmiotem. Warto zauważyć, że spory te korelują z doświadczeniem praktycznych skutków decyzji moralnej. Istnieje bowiem zależność między uznawaną koncepcją sumienia a działaniem oraz oceną tego działania. Chodzi o to, że w jednostkowym rozumieniu sumienia kryje się zawsze nie tylko pojęcie czegoś (specjalnej władzy, zmysłu, instynktu itp.), co formuje sądy moralne, lecz również praktyczna odpowiedź podmiotu formującego owe sądy. Przyjrzyjmy się pokrótce kilku sytuacjom, które zobrazują tę zależność.

Zdarza się, że w naszym działaniu i w jego ocenie kierujemy się głównie uczuciem. Dzieje się tak często wtedy, gdy robimy coś w pośpiechu, szybko, niejako instynktownie, na przykład rzucając drobną kwotę do puszki biednego, aby uczynić zadość współczuciu, które rodzi się w nas na jego widok. Tego typu działanie nie zawsze jest incydentalne, lecz może ono wynikać z postawy ukształtowanej przez długotrwałe podejmowanie decyzji w oparciu o uczucia lub emocje. Zupełnie inaczej dzieje się w przypadku, gdy nasze godziwe (choćby z punktu widzenia osoby trzeciej) działanie usprawiedliwiamy nakazem bądź zakazem przychodzącym z zewnątrz, na przykład gdy wspieramy potrzebującego, jedynie czyniąc zadość przyjętej powszechnie normie zakazującej obojętność wobec bliźniego. Tak zatem, czyniąc coś szlachetnego, możemy to robić z czystego obowiązku lub dla uniknięcia czyjejś uwagi, a niekoniecznie z wewnętrznego przekonania o godziwości i słuszności takiego postępowania. Dlatego, zarówno w pierwszej, jak i w drugiej sytuacji sąd sumienia wcale nie musi być słuszny, to jest nie musi odpowiadać naturze przedmiotu, którego dotyczy. W obu sytuacjach wiemy, co robimy (wspieramy biednego) i wiemy dlaczego to robimy (nakazuje nam to współczucie lub obowiązek wynikający z przyjętej normy), lecz nie zawsze potrafimy to działanie uzasadnić w oparciu o czynnik racjonalny, czyli niekoniecznie znamy odpowiedź na pytanie: dlaczego w ogóle powinniśmy postępować w określony sposób? Jeśli jedyną odpowiedzią na tak zadane pytanie jest: „ze względu na uczucie” lub „przez wzgląd na normy”, możemy się mylić. Uczucia, irracjonalne ze swej natury, nie mogą być kryterium prawdy. Kryterium tego nie znajdziemy też w samym nośniku danej normy, np. w zdaniu „nie zabijaj”, które samo w sobie nie zawiera odpowiedzi, ani na pytanie dlaczego mam nie zabijać ani na pytanie czy norma ta odnosi się do wszystkich w takim samym stopniu.

$\mathrm{Z}$ jeszcze innym obrazem sumienia spotykamy się w sytuacji, gdy o wyborze decyduje nieskrępowana niczym wola podmiotu. Wówczas sumienie jest 
instancją nie tyle reagującą na coś (uczucie, nakaz, poznanie), co instancją twórczą, wręcz kreatywną, która reaguje w niepowtarzalny sposób na indywidualne sytuacje. Jako takie stanowi ono decyzję, której podstawowa wartość tkwi w tym, że jest po prostu dziełem naszego wolnego wyboru. Jednak również w tym przypadku musimy liczyć się z możliwością pomyłki. Otóż, jeśli aktu woli (wyboru) nie zwiążemy z prawdą, naszemu działaniu zagrozi chaos. Mimo że uwolni się ono od wpływu namiętności, uczuć, nacisków, zasad, autorytetów itd., pozostanie w niewoli własnej wolności. Oderwane bowiem od porządku celowościowego (jedynym celem będzie w tym przypadku wolność wyboru) zostanie skazane na ślepy los lub przypadek.

Tym, co łączy opisane sytuacje jest fakt, że w żadnej z nich sąd moralny nie musi stanowić sądu w sensie logicznym, czyli zdania odpowiadającego jakiemuś stanowi rzeczy. W pierwszej (gdzie zasadą sądu moralnego są uczucia bądź emocje), a zwłaszcza w trzeciej (gdzie sąd sumienia jest efektem czysto subiektywnego wyboru) jego wartość, czyli moc wiążącą mierzy się tym, że autorem sądu moralnego jest sam podmiot odczuwający lub wybierający w jemu charakterystyczny sposób. Ks. Andrzej Szostek sytuację człowieka o tak ukształtowanym sumieniu porównuje do plasteliny, z której, choć nie wszystko da się ulepić, przynajmniej wolno lepić to, co się da (Szostek, 2009). Przyjmując taką koncepcję sumienia, możemy jednak pozbawić się kontaktu ze światem realnym, a w konsekwencji dowolnie kształtować, naginać i zmieniać rzeczywistość, dostosowując ją do własnych nastawień, planów, oczekiwań itd. Z kolei w drugiej z opisanych sytuacji wartość sądu moralnego mierzy się jego zgodnością z normą przyjętą za prawdę, którą podmiot uznaje, lecz nie reflektuje. Nie ma na nią wpływu, nie jest jej autorem, lecz jednocześnie nie chce, nie może lub nie potrafi zweryfikować jej słuszności.

Przyjrzyjmy się teraz koncepcji sumienia, w której zasadą sądu moralnego i jego słuszności jest zgodność z samym przedmiotem działania. Jedynie w tej koncepcji podmiot działania, nie przestając być autonomicznym twórcą sądów moralnych, jednocześnie nie traci kontaktu z otaczającym go światem. Łączy ona bowiem to, czego na pierwszy rzut oka nie da się pogodzić, a mianowicie podmiotowość z przedmiotowością. W tym przypadku przyczyną sprawczą działania jest współpraca rozumu (który poznaje) i woli (która chce) w dążeniu do dobra godziwego. Dzięki pierwszemu $\mathrm{z}$ nich sumienie jest po prostu sądem rozumu poznającego prawdę. Dzięki drugiej staje się ono zaangażowane od strony podmiotu. Przestaje być tylko recepcją czegoś, a staje się dobrowolnym zobowiązaniem. Takie ujęcie sumienia wypływa wprost z doświadczenia, które pokazuje, że w momencie poznania jakiejś prawdy, nawet najbardziej banalnej, w ślad za aktem 
poznania podąża akt woli polegający na uznaniu tejże prawdy. Oto prosty przykład: kiedy zapytani o aktualny stan pogody spoglądamy przez okno i widzimy, że pada deszcz, nie możemy odpowiedzieć, że świeci słońce. W przeciwnym razie zaprzeczylibyśmy nie tylko obiektywnemu stanowi rzeczy (deszcz faktycznie pada), ale przede wszystkim osobistej afirmacji tego faktu (ja nie tylko wiem, ale jeśli ufam swym zmysłom - uznaję, że tak faktycznie jest). Powinność, która rodzi się przez dobrowolne związanie się z poznaną prawdą, jest zatem niczym innym jak następstwem naszej odpowiedzialności za nią. Wracając do wcześniejszego przykładu, możemy powiedzieć, że przy tak funkcjonującym sumieniu, pomoc udzielona biednemu nie jest ani odpowiedzią na poryw współczucia, ani ślepym podporządkowaniem się normie społecznej lub kulturowej, lecz odpowiedzią na doświadczenie (w znaczeniu poznania bezpośredniego) i uznanie osoby w drugim.

Należy oczywiście uwzględnić fakt, że aktywność rozumu otwartego na prawdę i prawość woli w jej dążeniu do dobra nie tylko może, ale powinna ujawniać się w sytuacjach przedstawionych wcześniej, na przykład towarzysząc naszej uczuciowości i podążając w krok za każdym porywem serca. Podobnie rzecz ma się z każdą rozpoznawaną bądź kreowaną normą, której powinna towarzyszyć refleksja nad jej słusznością, czyli odniesieniem do dobra godziwego. Nawet jeśli wola staje przed zadaniem rozwiązania trudnej i niepowtarzalnej sytuacji sumienie nie pozwala podmiotowi na „samotne” (poddane jedynie woli jednostki) podejmowanie decyzji w oderwaniu od prawdy, która nigdy do końca od niego nie zależy. Ponadto, trzeba jeszcze zauważyć, że ostatnia $\mathrm{z}$ przywołanych koncepcji sprzeciwia się również przeakcentowaniu czynnika rozumowego w funkcjonowaniu sumienia. W działaniu godziwym nie chodzi bowiem o to, aby spełniać dobro moralne, lecz o to, aby je czynić. Do tego zaś ,nie wystarcza sama legalna zgodność z prawdą, ale potrzebna jest również wewnętrzna afirmacja tej prawdy, i to zarówno afirmacja intelektualna, emocjonalna, jak i wolitywna" (Biesaga, 2008). Otwartość na prawdę, która nie zależy od podmiotu, umożliwia mu przekroczenie własnej immanencji, to jest nie tylko własnych przekonań sądów, ale również ograniczeń (niechęci, nastawień, przesądów itp.). Jak widać czynienie, które nie jest jedynie spełnianiem dobra, wymaga aktywności całego podmiotu, jego rozumu, woli i uczuć. Dopiero dzięki tej współpracy dobro obiektywne ma szansę stać się faktycznie naszym dobrem, które przyjmujemy, chcemy się nim kierować, a w końcu potrafimy je realizować we własnym działaniu.

Oczywiście sumienie jako sąd praktyczny może się mylić, dlatego że korzysta ono $\mathrm{z}$ informacji pochodzących z poznania teoretycznego, które bywa zawodne. Ileż razy, będąc przekonanymi o prawdziwości jakiegoś sądu czy opinii po jakimś 
czasie uświadamialiśmy sobie pomyłkę lub błąd poznawczy. Dlatego sama zgodność z sumieniem nie gwarantuje jeszcze słuszności działania. Okoliczności te nakładają na nas obowiązek starannego poznawania dobra, które ma się stać celem naszego działania oraz troski o prawość intencji woli (Woroniecki, 1986). Chodzi o to, aby nasza wola chciała poznawać rzeczy takimi, jakimi są i zaakceptować prawdę o nich. W deformacjach woli tkwi być może przyczyna najpoważniejszych błędów sumienia ${ }^{1}$.

W tym, co dotychczas powiedziane, chodzi o pokazanie, że błąd sumienia, choć w sensie ścisłym dotyczy deformacji samej władzy poznawczej (rozumu praktycznego) w zakresie poznania i wybierania przez nią dobra moralnego, dotyczy również, choć w nieco innym znaczeniu, rozumienia tej władzy. Jej pełne ujęcie odnosi się do aktu rozumu i woli, a nie tylko rozumu lub woli, bądź ewentualnie woli skorelowanej z uczuciem lub normą zewnętrzną wobec podmiotu. Błędna identyfikacja sumienia, poprzez związek jaki zachodzi między theoria a praxis, na terenie tej drugiej może powodować skutki podobne do tych, które niesie deformacja samego sumienia, dlatego że sposób postrzegania sumienia koresponduje z podejściem (nie tylko teoretycznym) do samego siebie, drugiego człowieka, w końcu do rzeczywistości. Kwestie te nabierają szczególnego znaczenia, kiedy chodzi o wychowanie, zwłaszcza wychowanie moralne, gdzie kwestia sumienia jest sprawą zasadniczą. Nawet gdybyśmy wyrugowali to pojęcie z teorii wychowania moralnego, w praktyce jest to niewykonalne. Posiadając bowiem faktyczną intencję czynienia dobra, musimy posiadać kryterium odczytania i oceny tego dobra, co nie jest możliwie bez pośrednictwa odpowiedniej dla tych zadań instancji.

\section{PRZEKRACZANIE BŁĘDÓW SUMIENIA A OBIEKTYWNA WARTOŚĆ DOBRA MORALNEGO}

Słowo „przekraczanie” w dziedzinie moralności zazwyczaj przywołuje się nie w kontekście transcendowania błędów sumienia, lecz właśnie jego sądów; przekraczania norm, tabu, zakazów, wstydu itd. Przekraczanie utożsamia się tutaj z negacją, pomniejszeniem lub pominięciem czegoś, co człowiek odczytuje

\footnotetext{
${ }^{1}$ Przekonujący obraz tego problemu przedstawia Shakespeare. W znanej tragedii ukazuje Henryka VIII, który szukając sposobu na porzucenie żony, doświadcza nagle (po 14 latach małżeństwa!) „wyrzutów sumienia” płynących ze świadomości powinowactwa istniejącego między nim a małżonką. Jego wynaturzone sumienie zostaje wykorzystane, aby faktycznie działać wbrew sumieniu. (zob. Shakespeare, 1980).
} 
w kategoriach ograniczeń. Takiemu zgoła negatywnemu rozumieniu należy jednak przeciwstawić rozumienie pozytywne. Chociaż oba bazują na zjawisku „wychodzenia ponad” to, czym jesteśmy, co potrafimy, posiadamy lub znamy, pozytywne rozumienie transgresji ma za podstawę inne treści poznawcze i dotyczy innej motywacji woli. W rozumieniu negatywnym przekraczamy normę, w rozumieniu pozytywnym przekraczamy własne ograniczenia po to, aby normę zrealizować (nie bez powodu w różnych religiach czas przemiany wewnętrznej związany jest z postem lub trwaniem w odosobnieniu). W tym drugim znaczeniu nie chodzi o przekraczanie dla zaprzeczenia albo dla samego przekraczania bądź dla tworzenia nowych wartości w opozycji do zastanych, lecz na odkryciu czegoś, co wykracza poza nas samych i co przedstawia wartość samą w sobie. Przy czym ów przedmiot, który powoduje, że decydujemy się na przekraczanie samych siebie, jest tu czymś, co może nas realnie udoskonalić w określonej dziedzinie działania lub wiedzy, bądź w ogóle udoskonalić nasz byt. Natomiast granice, które stawiamy sobie samym, własnemu egoizmowi, dążeniu do przyjemności itd., potwierdzają naszą wolność i są jej właściwym wyrazem (zwierzęta nie potrafią się samoograniczyć). Dlatego wolność ta, mimo że nas ogranicza, jednak wcale nie zniewala.

Wracając do błędu sumienia, zazwyczaj określa się go jako działanie (zawinione bądź nie) niezgodne z jakąś normą moralną. Wadliwość sumienia wiąże się jednak często $\mathrm{z}$ brakiem wysiłku w celu identyfikacji zasady tej normy. Zasady, której rozpoznanie nie zawsze jest oczywiste. Np. normie „nie zabijaj” przypisuje się czasem sprzeczne zasady, takie jak: wartość życia, interes grupy czy wolna decyzja. Pierwsza z wymienionych (wartość życia) powoduje powszechność opartej na niej normy, ale już zgodne z interesem społecznym byłoby czasem jej złamanie, natomiast czyjś wolny wybór mógłby zadecydować zarówno o przyjęciu tej normy (w stosunku do drugiego lub siebie), jak i jej odrzuceniu. Jednak powszechność prawa moralnego bierze się stąd, iż jako ludzie, mimo że mamy udział w kreowaniu obrazów tego, co istnieje (np. drugiego człowieka, którego możemy postrzegać jako intruza, wroga, brata, konkurenta albo normy jako godzącej w wolność, potwierdzającej wolność bądź będącej dla niej wyzwaniem), nie mamy wpływu na to, że w ogóle istnieje, ani na to, że jest już jakoś określone, stanowi konkret dany do odczytania i zrozumienia. Zadanie to nie zawsze jest proste, o czym świadczy choćby fakt, że czasem z pewnych względów trudno nam dojrzeć lub uznać człowieka w drugim. Niemniej jednak, odrzucając bądź lekceważąc rzeczywistość daną do zrozumienia i oswojenia, rezygnujemy z możliwości uczenia się z niej, a niekiedy nawet ocalenia własnego człowieczeństwa, o czym, może najwyraźniej, mówią sytuacje graniczne, np. choroba, 
śmierć, niepełnosprawność, które zmuszają do zabrania głosu w sprawie wartości podstawowych. Kolejną sprawą związaną z tym, że źródło normy moralnej leży poza nami, jest fakt, że pomimo tego, iż jest ona nasza (moja, twoja, jego itd.) w tym sensie, że ostatecznie jesteśmy jej autorami, swoje źródło posiada w czymś poza nami. Dlatego sumienie tradycyjnie nazywano również „współwiedzą” lub „współrozumieniem”. Termin ten wywodzi się od łacińskiego - conscientia (con razem z, współ-, scientia - wiedza) dla oznaczenia wspólnej wszystkim zdolności intelektu do odczytywania zasad postępowania. Zdolność ta polega na wykorzystywaniu wiedzy i roztropności do wyłaniania szczegółowego, prawdziwego i słusznego sądu moralnego (Biesaga 2008, s. 267n).

Obecnie błąd moralny lub winę moralną, a nawet samo sumienie często wiąże się głównie z płaszczyzną religijną. Natomiast już wyłącznie religijne znaczenie przypisuje się słowu ,grzech”. Mało kto wie, że pojęcie grzechu było znane już w starożytności, zresztą nie tylko w kulturze żydowskiej. Na przykład dla Greków termin „grzech”, mimo że posiadał konotację religijną, oznaczał też coś innego, aniżeli jedynie sprzeniewierzenie się prawu boskiemu. Termin ten odnosił się wówczas do różnego typu działalności i posługiwano się nim zarówno w dziedzinie moralności, jak i w dziedzinie sztuki artysty. Błąd na polu artystycznym był większy wówczas, gdy został popełniony nieświadomie. Inaczej na polu moralności, gdzie to stopień udziału władz intelektualnych określał wagę błędu (Maritain, 2001, s. 177n). Tak zatem rzeźbiarz, który celowo uchybiał zamysłowi swojego dzieła lub łamał zasady sztuki rzeźbiarskiej (na przykład w celu uzyskania poklasku publiczności bądź uznania jury), wedle tej koncepcji popełniał grzech w stosunku do swojego dzieła. Był on jednak mniejszej wagi od tego, który artysta popełniał nieświadomie. Pierwszy mógł się przytrafić nawet geniuszowi, mógł bowiem wynikać ze słabości jakiejś cechy jego charakteru, niekoniecznie zaś z braku zdolności. Drugi natomiast świadczył o słabości artysty jako artysty, jego niewiedzy, braku kompetencji itp. Inaczej rzecz ma się na polu moralności. Tutaj grzech dotyczy sztuki dobrego życia i również odnosi się do określonego kanonu zachowań. Jest on jednak poważniejszy, gdy czynimy go z premedytacją, znając kwalifikację moralną popełnianego czynu. Błąd w dziedzinie moralności jest bardziej wolicjonalny. Ukazuje słabość człowieka jako człowieka, który dobrowolnie, w pełnej świadomości normy, popełniając zło, sam staje się zły. Oczywiście błąd taki dotyczy również artysty, ale tylko wtedy, gdy jego dzieło kłamie, upokarza lub w inny sposób urąga wartościom, stojącym ponad dziełem. Dziedzina moralności jest bowiem znacznie szersza od innych pól aktywności człowieka i odnosi się do każdego z nich, jeśli tylko w grę wchodzi 
wartość moralna czynu. Ta zaś pojawia się wszędzie tam, gdzie przedmiot i cel naszego działania związane są z realizacją niezależnego od nas, obiektywnego dobra, którego afirmacja bądź negacja buduje nas lub degraduje jako osoby.

\section{ZAKŁAMANIE}

Błąd sumienia może być jednorazowym zaprzeczeniem tego dobra lub trwałym uformowaniem władz intelektu sprzyjającym tej negacji. Różnicę między tymi błędami opisał już Arystoteles w swojej Etyce nikomachejskiej (Arystoteles, 1982). Poniżej wskażę jeden z nich, skupiający w sobie zarówno błędną identyfikację samego sumienia, jak i będące jej skutkiem wadliwe rozpoznanie, a właściwie negację normy moralności (kryterium dobra moralnego). Chodzi o zakłamanie, które w perspektywie pedagogicznej stanowi być może najpoważniejszą i najbardziej oporną na zmianę deformację rozumu praktycznego.

Zakłamanie, inaczej autokłamstwo (Chudy, 2003), jest to wada moralna zakorzeniona $\mathrm{w}$ próbach podporządkowania rzeczywistości własnym pragnieniom, życzeniom bądź poglądom. W skrajnych przypadkach może ona prowadzić do sytuacji, w których podmiot moralny przestaje sobie zdawać sprawę z faktu, że żyje w tkanej przez samego siebie, niekiedy całymi latami, zwartej sieci kłamstw. Deformacja ta swoje początki ma jednak w błędach sumienia podejmowanych zwykle w sposób zupełnie wolny i świadomy. Tak na przykład student, który ściąga na egzaminie, mimo że zdaje sobie sprawę z oszustwa, przywołuje różne jego racje, aby uzasadnić takie zachowanie. Wyjaśnia sobie, że do ściągania skłoniła go chęć uzyskania wyczerpującej odpowiedzi. Fakt, że starał się o stypendium, dodatkowo wzmocnił siłę wskazanego motywu. Ponadto, wykładowca nie pilnował sali, zatem okoliczności były nader sprzyjające. W końcu, prawie wszyscy ściągali, dlaczego on jeden miałby się wyłamać. Ostatecznie dochodzi do wniosku, że właściwie dobrze zrobił. Na podobny błąd może być narażony również nauczyciel nieuczciwego studenta. Otóż, chcąc sprostać stawianym mu wymaganiom, może na przykład zacząć pracować na swoiście rozumiany akord, przedkładając ilość nad jakość swoich wytworów. Tak zatem multiplikuje dorobek, nie zważając na fakt, że kolejne teksty powielają treści poprzednich lub są sprawozdaniem z cudzych badań. Zgłasza się na liczne konferencje, wiedząc, że de facto nie wygłosi nic nowego. W ten sposób zaczyna okłamywać samego siebie w imię podobnej zasady, którą pokierował się student: „wszyscy tak robią”. Preferencja przeciętności, strach o studia/pracę i wyścig do stopni, stopniowo zabijają w obu pasję badawczą i coraz bardziej przekonują o słuszności takiego działania. 
W obu przypadkach mamy do czynienia już z pewnym etapem zakłamania. Jego początków należy jednak szukać w przestrzeni wewnętrznego dialogu, dokonującego się w aktach refleksji nad samym sobą, własnym postępowaniem, przekonaniami, wiedzą. Akty te wyjaśniają brak wewnętrznej sprzeczności w słowie „autokłamstwo”. Dokonując refleksji nad samym sobą, człowiek jest zarazem nadawcą i odbiorcą, podmiotem i przedmiotem komunikacji między samym sobą a tym, co go wewnętrznie buduje. Taki stan rzeczy powoduje, że może nie tylko badać i poznawać własne myśli, pragnienia, wspomnienia, wyobrażenia itd., ale jak w każdej komunikacji, może je zakłamywać, co pokazał powyższy przykład. „W przypadkach ekstremalnych samooszukiwanie sprawia, że mówimy nieprawdę z uczuciem szczerości” (Chudy, 2003, s. 410). W ten sposób nieuczciwy student może być nie tylko przekonany o swojej niewinności, a nawet zgłaszać szczere pretensje do profesora o zbyt niską ocenę, a pracownik naukowy szczerze szczycić się ze swoich „osiągnięćc. Ale (uwaga!), przełamując granice, które sami sobie postawili (pierwszy - przychodząc na studia, drugi decydując się na bycie naukowcem), zanegowali wartości budujące etos studenta i nauczyciela. Nie są to ani wartości subiektywne, ani wymienialne na inne, lecz obiektywne, wchodzące w samą strukturę bycia studentem i bycia nauczycielem. Mało tego, wprawiony w bieg mechanizm samooszustwa stłumił wartość względem nich podstawową, a mianowicie prawdę, która usensownia zarówno studiowanie, jak i pracę naukową.

Mechanizm autokłamstwa może też posiadać taki sam kierunek, ale o przeciwnym zwrocie. Ma to miejsce w sytuacjach, kiedy to nie my zakłamujemy swoje myślenie i działanie, lecz odwrotnie, dajemy się oszukać temu, co buduje naszą wiedzę, opinie czy poglądy. Wówczas źródło kłamstwa tkwi nie w podmiocie, lecz $\mathrm{w}$ tym, co podmiot uznaje za prawdziwe i słuszne, np. w osobie, którą uważamy za autorytet, w wyznawanych poglądach, w linii partii, z którą się utożsamiamy itd. $\mathrm{W}$ tego typu sytuacjach nie kieruje nami intencja okłamania samych siebie, raczej ulegamy brakowi motywacji do weryfikowania przyjmowanych treści. Nie zadajemy sobie trudu, aby poznać i ocenić to, co buduje nasz pogląd na świat. Przyjmując czyjeś słowa albo na wiarę, albo dla wygody, albo dla uniknięcia konfliktu, również okłamujemy samych siebie. Godzimy się na to, aby nieprawdziwe treści budowały wiedzę, którą posługujemy się w życiu. Mechanizm ten dobrze obrazuje sposób działania niektórych mediów, pewne zjawiska znane z kultury, jak też niektóre zachowania z życia codziennego. Przyjrzyjmy się dwóm $\mathrm{z}$ nich.

Przykładem autokłamstwa w skali mikro może być nadopiekuńcza matka, która z miłości do swego jedynego dziecka roztacza nad nim szczelny parasol 
swojej opieki, chcąc je ochronić przed wszelkim złem tego świata. Wyręcza je w najdrobniejszych pracach i tłumaczy każde przewinienie. Zaślepiona miłością może nie zauważyć, że największą krzywdę wyrządza dziecku ona sama. Zamiast uczyć je samodzielności, coraz bardziej uzależnia od siebie, zamiast zauważać jego złe skłonności i przeciwdziałać im, hołduje wadom. A czyni to wszystko z miłości. Przykład ten pokazuje, że nawet dobra intencja i szczytny cel nie przesądzają o słuszności działania, które najpierw trzeba uzgodnić z obiektywnym stanem rzeczy, a nie z subiektywną prawdą o nim.

Przykładem zakłamania w skali makro mogą być transgresje na polu artystycznym, dokonywane $\mathrm{w}$ imię wolności, obnażania schematów, a nawet $\mathrm{w}$ celach edukacyjnych. Tak na przykład, cieszące się coraz większą popularnością wystawy spreparowanych ludzkich ciał, w opinii organizatorów mają służyć za dzieło sztuki będące wyrazem najwyższej klasy artyzmu plastynacji ludzkiego ciała lub za najbardziej poglądowy (bo najbardziej realistyczny) model anatomiczny (np. Human Body Exhibition). Dodać trzeba, że wskazane działania nie są pozbawione aspektu merkantylnego, gdyż za oglądanie martwych ciał trzeba zapłacić. Ponadto nie mają nic wspólnego z sekcją zwłok, podczas której studenci faktycznie poznają ciało człowieka, jednak nie po to, aby nim się zachwycić, zadziwić, zgorszyć, albo zaspokoić swoją ciekawość, lecz po to, aby w przyszłości umieć je leczyć. Działania takie, przesuwając granice naszej wrażliwości, w dziwny sposób nie kłócą się z jednoczesnym pielęgnowaniem pamięci o Szoah, którego inżynierowie w sposób równie ,artystyczny” podchodzili do ludzkiego ciała. Ono jednak nawet po śmierci człowieka nie przestaje go wyrażać, nadal jest ciałem ludzkim i nosi w sobie tajemnicę naszego istnienia. Nie staje się ani tylko rzeczą na sprzedaż, ani tylko eksponatem muzealnym, ani tylko tworzywem dla artysty.

Dlaczego jednak tak łatwo uwierzyć w moralną neutralność tego typu działań, a w konsekwencji ulec samooszustwu? Wydaje się, że po pierwsze dlatego (co akurat powinno cieszyć), iż wciąż jeszcze wierzymy artystom, nauczycielom i naukowcom, ufając, że etos ich pracy zbudowany jest na prawdzie. Po drugie (co z kolei jest przejawem braku dojrzałości), przestajemy stawiać granice samym sobie. Wolimy, aby czynił to ktoś inny, choć paradoksalnie wydaje się, że jest inaczej. Wiąże się to $\mathrm{z}$ mniejszym wysiłkiem, jak też z większą łatwością ich zanegowania. Po trzecie, zapominamy, że autonomia moralna polega na podejmowaniu decyzji wolnych i kreatywnych, przy jednoczesnym wiązaniu ich z prawdą o rzeczy, której dotyczą, a która niekiedy jest dla nas tak bardzo niewygodna i wymagająca.

Na zakończenie jeszcze raz przywołajmy słowa ks. prof. A. Szostka, zdaniem którego „przekonanie o tym, że wyrzuty sumienia nękać będą każdego złoczyńcę, 
uznać trzeba za niebezpiecznie naiwne złudzenie. Zamknąwszy dostęp prawdy do siebie, człowiek zdolny jest dokonywać najokrutniejszych zbrodni w poczuciu moralnej powinności, a nawet $\mathrm{w}$ przekonaniu o tym, że działa $\mathrm{w}$ imię prawdy, którą sam najpierw zniewolił" (Szostek, 2009, s. 173). Dlatego podstawowa trudność w przekraczaniu błędów sumienia, będąca zarazem jednym z zasadniczych wyzwań wychowania moralnego, wynika z faktu, że mogą one na trwale zdeformować nasze myślenie i działanie. Natomiast zmian na płaszczyźnie rozumu praktycznego możemy dokonać tylko my sami. Nie zrobi tego za nas żaden nauczyciel, rodzic czy wychowawca. Mogą oni oczywiście pobudzać aktywność naszych władz duchowych, jednak nie mają na nie bezpośredniego wpływu. „Moc” edukacji nie sięga naszego wnętrza, którego kształt i kierunek rozwoju ostatecznie sami określamy. Natomiast najważniejszym świadkiem i zarazem podstawą wszelkich faktycznych (a nie jedynie deklaratywnych) przeobrażeń na płaszczyźnie moralnej są nasze władze intelektualne. Fakt ten, czyniąc z nas jednocześnie przedmiot i podmiot wychowania, jest zarazem nie lada wyzwaniem. Otóż, jako ostateczni sędziowie nie tylko w sprawach własnego sumienia, jego pojęcia i treści, ale też w sprawie kierunku, decyzji i oceny własnego działania - tylko my możemy się zdecydować na sanację własnego wnętrza. Jest to zadanie nie tylko trudne, ale niekiedy wręcz niewykonalne.

\section{BIBLIOGRAFIA}

Arystoteles (1982). Etyka nikomachejska. Warszawa: Państwowe Wydawnictwa Naukowe.

Biesaga, T. (2008). Sumienie. W: A. Maryniarczyk (red.), Powszechna Encyklopedia Filozofii. T. 9 (s. 267-270). Lublin: Polskie Towarzystwo św. Tomasza z Akwinu.

Maritain, J. (2001). Dziewięć wykładów o podstawowych pojęciach filozofii moralnej. Lublin: Redakcja Wydawnictw KUL.

SzosteK, A. (2009). Otwartość na prawdę fundamentem wychowania sumienia. W: K. KRAJEWSKI (red.), Racjonalność w etyce. Sumienie: prawość i twórczość. Lublin: Wydawnictwo KUL.

WORONIECKI OP, J. (1986). Katolicka etyka wychowawcza. W: Etyka ogólna. T. 1. Lublin: Redakcja Wydawnictw KUL.

Chudy, W. (2003). Filozofia kłamstwa. Warszawa: Oficyna Wydawnicza Volumen.

ShaKespeARE W. (1980). Stawna historia żywota Króla Henryka VIII. Kraków: Wydawnictwo Literackie. 


\section{O NIEKTÓRYCH BŁĘDACH SUMIENIA I TRUDNOŚCIACH W ICH PRZEKRACZANIU}

\section{Streszczenie}

Przedmiotem artykułu jest wadliwość sumienia. Część pierwsza prezentuje wybrane koncepcje sumienia oraz praktyczne skutki ich przyjęcia. W dalszej kolejności przedstawiona jest argumentacja na rzecz tezy, że zachodzi konieczny związek między przekraczaniem błędów sumienia a rozpoznaniem obiektywnej wartości dobra moralnego. Ostatnia część artykułu została poświęcona zakłamaniu, które oparte na błędnej koncepcji sumienia, stanowi jego najbardziej oporną na zmiany deformację.

Słowa kluczowe: sumienie; koncepcja sumienia; błąd sumienia; zakłamanie; wychowanie.

\section{ON FALLACIES OF CONSCIENCE. THE DIFFICULTIES CONCERNING OVERCOMINGS OF CONSCIENCE'S DEFECTIVENESS}

\section{S u m mary}

The paper concerns the defectiveness of conscience. I start with description of conscience's concepts and the practical results of its acceptance. Then I argue for the thesis that cognition of moral good's objective value is necessary for the overcomings defectiveness of conscience. Finally I formulate the concept of mendacity as the form of conscience defect the most resistant to changes.

Key words: conscience; concept of conscience; fallacy of conscience; mendacity; education. 